Article

\title{
Hydration of Hybrid Alkaline Cement Containing a Very Large Proportion of Fly Ash: A Descriptive Model
}

\author{
Inés Garcia-Lodeiro *, Shane Donatello, Ana Fernández-Jiménez and Ángel Palomo \\ Cement and Recycling Materials Department, Eduardo Torroja Institute (IETcc-CSIC), Madrid 28033, Spain; \\ shane.donatello@ec.europa.eu (S.D.); anafj@ietcc.csic.es (A.F.-J.); palomo@ietcc.csic.es (Á.P.) \\ * Correspondence: iglodeiro@ietcc.csic.es; Tel.: +34-91-30-20-440 \\ Academic Editor: Arie van Riessen \\ Received: 24 May 2016; Accepted: 18 July 2016; Published: 22 July 2016
}

\begin{abstract}
In hybrid alkaline fly ash cements, a new generation of binders, hydration, is characterized by features found in both ordinary portland cement (OPC) hydration and the alkali activation of fly ash (AAFA). Hybrid alkaline fly ash cements typically have a high fly ash (70 wt \% to $80 \mathrm{wt} \%)$ and low clinker (20 wt \% to $30 \mathrm{wt} \%$ ) content. The clinker component favors curing at ambient temperature. A hydration mechanism is proposed based on the authors' research on these hybrid binders over the last five years. The mechanisms for OPC hydration and FA alkaline activation are summarized by way of reference. In hybrid systems, fly ash activity is visible at very early ages, when two types of gel are formed: C-S-H from the OPC and N-A-S-H from the fly ash. In their mutual presence, these gels tend to evolve, respectively, into $\mathrm{C}-\mathrm{A}-\mathrm{S}-\mathrm{H}$ and $(\mathrm{N}, \mathrm{C})-\mathrm{A}-\mathrm{S}-\mathrm{H}$. The use of activators with different degrees of alkalinity has a direct impact on reaction kinetics but does not modify the main final products, a mixture of $\mathrm{C}-\mathrm{A}-\mathrm{S}-\mathrm{H}$ and $(\mathrm{N}, \mathrm{C})-\mathrm{A}-\mathrm{S}-\mathrm{H}$ gels. The proportion of each gel in the mix does, however, depend on the alkalinity generated in the medium.
\end{abstract}

Keywords: hybrid alkaline cement; alkaline activation; fly ash; geopolymer; descriptive hydration model; gel microstructure

\section{Introduction}

Modern construction is unthinkable without ordinary portland cement (OPC), the fundamental binder in concrete. According to CEMBUREAU data, some four billion tons of PC were manufactured worldwide in 2013 alone. With the use of fossil fuels to raise kiln sintering temperatures to around $1450{ }^{\circ} \mathrm{C}$ and the limestone decarbonation required to produce raw meal, the industry accounts for approximately $5 \%-8 \%$ of anthropogenic $\mathrm{CO}_{2}$ emissions [1].

Attempts to reduce its $\mathrm{CO}_{2}$ footprint by blending OPC with supplementary cementitious materials (SCMs), such as coal fly ash, metakaolin or blast furnace slag [2], have yielded pozzolanic cements with technical properties comparable to those of ordinary cement [3]. Nonetheless, such blended cements contain $70 \mathrm{wt} \%$ to $90 \mathrm{wt} \%$ OPC. On the opposite end of the spectrum are alkali-activated binders containing $0 \mathrm{wt} \%$ OPC. There the reactive solid is an aluminosilicate material prone to dissolution under highly alkaline conditions. Given the important role of aluminosilicate phases, generally speaking materials that hold promise as alkali-activated cements also exhibit pozzolanic activity in blended cements: i.e., coal fly ash [4,5] and metakaolin [6]. The hydration of these alkali-activated cements, also termed geopolymers, which has been studied in considerable detail over the last 10-15 years, has been shown to be governed by mechanisms that are different to OPC. The major difference between the two is that alkali activated cements are mixed not with water but 
highly alkaline chemicals [7-9]. In addition, in the case of fly ash, a moderately high curing temperature $\left(60^{\circ} \mathrm{C}\right.$ to $\left.90^{\circ} \mathrm{C}\right)$ is required to ensure practical reaction kinetics [10].

Fly ash is the supplementary cementitious material most widely used, ton for ton. Taking OPC and alkali-activated fly ash (AAFA) as the two extremes on a spectrum, blended cements containing fly ash (pozzolanic cements) would represent the middle ground. The ceiling fly ash dry mass content in pozzolanic binders is usually set at $20 \%$ to $55 \%$ [11]. Because the pozzolanic reaction of fly ash is fairly slow, early age strength has been shown to be lower and setting times longer in cements with a high FA content than in other pozzolanic binders [12]. Attempts made to surmount these drawbacks include the use of quick-setting cement [13] or the addition of limestone to the mix $[14,15]$.

Alternatively, a suitable alkali may be used to enhance fly ash reactivity [16,17]. Research is underway at this time on what are known as 'hybrid alkaline fly ash cements' [18-26], typically binders with a low Portland cement and a fly ash content significantly higher than in blended pozzolanic cements. The source of the alkali may be a highly alkaline solution, used in lieu of mixing water, a solid or a dissolved $\mathrm{Na} / \mathrm{K}$ compound. In all three cases, the hybrid alkaline cements react and can be cured at ambient temperature. These cements can also be regarded to lie in an intermediate position on the OPC/alkali activation of fly ash (AAFA) spectrum, as illustrated in Figure 1.

While much research has been conducted on the mechanisms governing hydration in OPC [27-29], pozzolanic [30,31] and AAFA [32-34] cements, very little has been published on the hydration mechanisms in hybrid alkaline systems

This paper aims to describe the hydration mechanisms taking place in fly ash-high hybrid alkaline cements and define the main characteristics of the cementitious gel forming in those systems. Given the significant role of the nature of the alkaline admixture in such cements, it is also discussed hereunder.

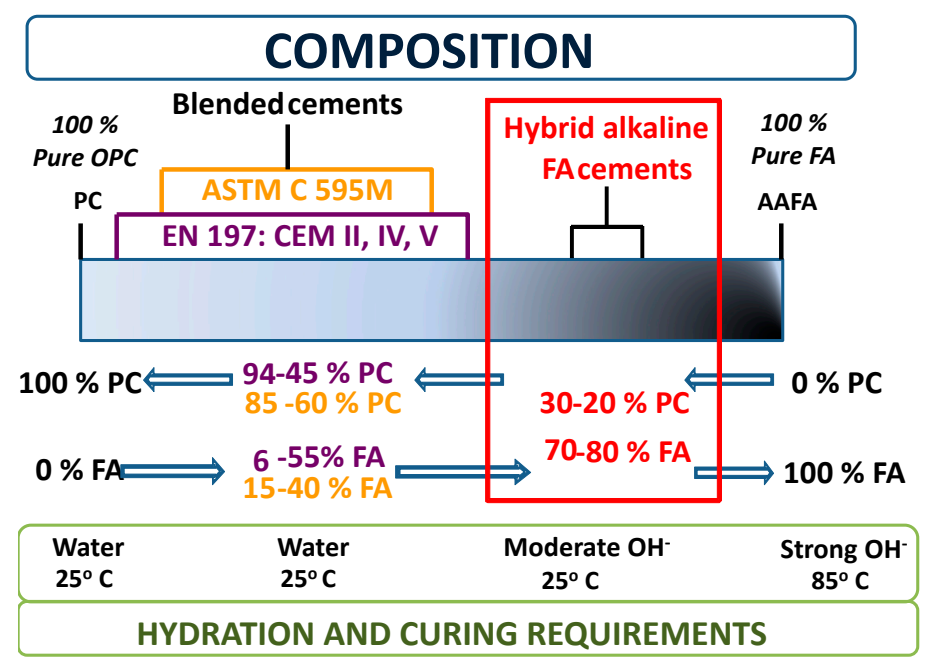

Figure 1. Position of hybrid alkaline fly ash cements on the pure Portland cement (PC)-pure alkali activation of fly ash (AAFA) spectrum, relative to pozzolanic fly ash cements.

\section{Background}

Inasmuch as hybrid alkaline cements may be regarded to lie somewhere between the two extremes defined by OPC and AAFA, a brief discussion of the hydration mechanisms present in the latter two systems is in order, applying the same methodology as subsequently used to describe the model proposed for hybrid cements.

\subsection{Portland Cement (PC) Hydration}

Portland cement clinker consists primarily in four reactive phases: Alite $\left(C_{3} S\right)$, belite $\left(C_{2} S\right)$, tricalcium aluminate $\left(\mathrm{C}_{3} \mathrm{~A}\right)$ and ferrite $\left(\mathrm{C}_{4} \mathrm{AF}\right)$. The most reactive of these components are $\mathrm{C}_{3} \mathrm{~A}[35,36]$ 
and $C_{3} S$ [37-39]. A single grain of cement may be divided into several regions containing different clinker phases. Figure 2 shows a widely accepted descriptive model [40] (first proposed by Scrivener in 1984) [41]. Figure 2, also reproduces a typical calorimetric analysis of OPC hydration for comparison.

Further to Figure 2, a very intense but short-lived exothermal peak generated by the rapid dissolution of the surfaces of $\mathrm{C}_{3} \mathrm{~S}$ and $\mathrm{C}_{3} \mathrm{~A}$ concurs with the initial wetting of cement grains. Clinker dissolution raises the liquid phase $\mathrm{pH}$ substantially, along with $\mathrm{Ca}^{2+}, \mathrm{Al}^{3+}$ and silicate ion concentrations. The sulfate present in the gypsum induces a decline in $\mathrm{Al}^{3+}$ concentration in the liquid phase due to the precipitation of tiny ettringite (AFt) prisms. $\mathrm{C}_{3} \mathrm{~A}$ hydration is subsequently inhibited by the presence of sulfate ions. The reason advanced is that the AFt forms layers on the surface of the $\mathrm{C}_{3} \mathrm{~A}$ grains, making it inaccessible to the liquid phase [40]. Early age precipitation of $\mathrm{C}-\mathrm{S}-\mathrm{H}$ or $\mathrm{C}-(\mathrm{A})-\mathrm{S}-\mathrm{H}$ gels on the surface of clinker grains also lowers effective clinker solubility and with it the rate of heat released to a characteristic minimum during the induction period.

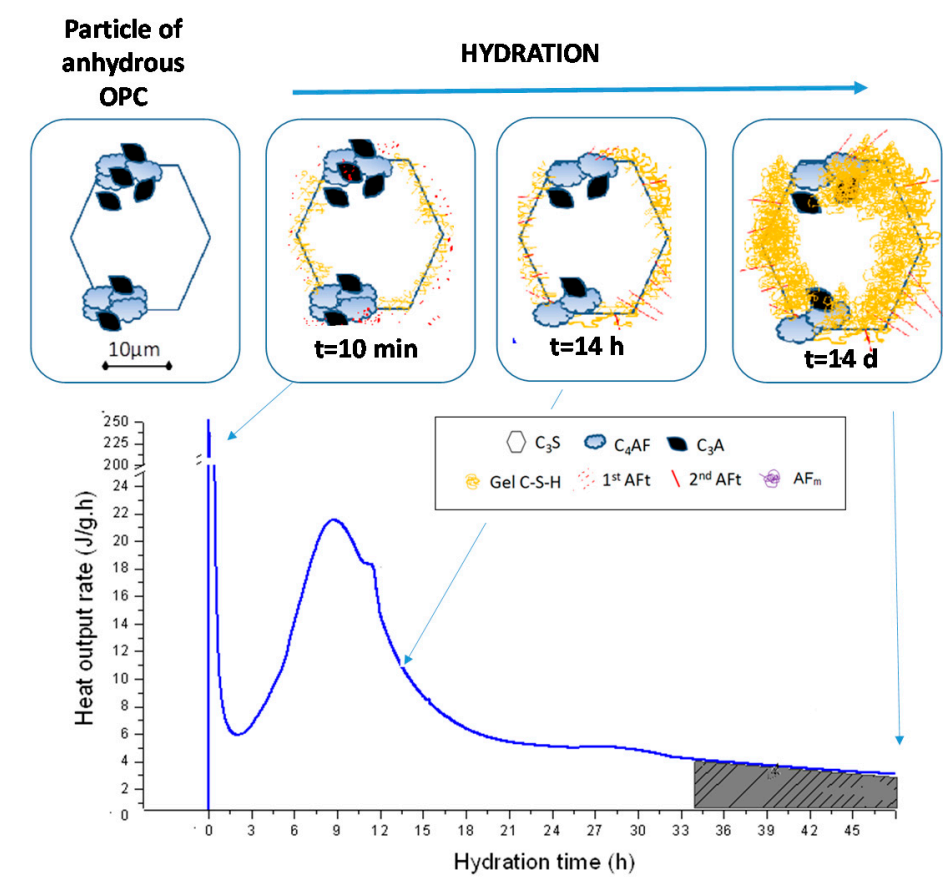

Figure 2. Descriptive model for poly-phase OPC grain hydration and a typical calorimetric curve for OPC hydration (grain drawings adapted from Scrivener as quoted in Taylor (1997) [27]).

While continuing at a much slower rate, clinker hydration does not stop altogether during the induction period. $\mathrm{Ca}$ and silicate ion concentration in the liquid phase gradually rises until large amounts of $\mathrm{C}-\mathrm{S}-\mathrm{H}$ gel precipitate, removing the $\mathrm{Ca}$ and silicate ions from the solution and favouring the resumption of $\mathrm{C}_{3} S$ phase hydration [42,43]. That leads to the formation of large amounts of so-called 'outer' C-S-H gel, with the coalescence of cement particles to which cement paste setting is attributed [44]. This period of massive gel precipitation, termed the acceleration period, constitutes the predominant exothermal event in PC hydration after initial wetting.

As sulfate ion activity declines in the liquid phase, the $\mathrm{C}_{3} \mathrm{~A}$ grain surfaces come into direct contact with the liquid and the reaction resumes, forming larger 'secondary ettringite' prisms. The resumption of $\mathrm{C}_{3} \mathrm{~A}$ hydration is often visible in calorimetric data as a shoulder on the downward slope of the acceleration stage, although at times it is undistinguishable from the main acceleration/deceleration peak. 'Inner' C-S-H gel also gradually forms in this period.

As the amount of inner C-S-H gel rises, lowering sulfate availability, monosulfate (AFm) is favored over trisulfate (AFt) formation. Although the mechanism has yet to be accurately described, the larger AFt prisms appear to be unaffected, since as a rule the lower relative surface area renders 
larger crystals more stable than smaller ones $[45,46]$. The conversion of AFt to AFm or the reaction between $\mathrm{C}_{3} \mathrm{~A}$ and $\mathrm{AFt}$ to form $\mathrm{AFm}$ is sometimes visible in the form of a low intensity, wide exothermal peak appearing between days 1 and 3 . The fairly small amount of heat that continues to be generated even after three days can be attributed to the ongoing hydration of $C_{3} S$ grains, with the formation of more inner $\mathrm{C}-\mathrm{S}-\mathrm{H}$ gel. That process is related to the significant gains in compressive strength observed in PC pastes after the second day.

The nanostructure of the resulting C-S-H gel consists of a central layer of octahedrally orientated $\mathrm{Ca}-\mathrm{O}$ units sandwiched by upper and lower layers of imperfect silicate tetrahedral chains. These chains are formed from units consisting of three tetrahedra in which two are linked by a third, the 'bridging' tetrahedron. The predominance of $\mathrm{Q}^{1}$ (end of chain) and $\mathrm{Q}^{2}$ (mid-chain) units in ${ }^{29} \mathrm{Si}$ MAS NMR spectra confirms that the silicate chains in C-S-H gel are weakly polymerized $[27,47,48]$.

\subsection{Alkali-Activated Fly Ash Cement Hydration}

As noted earlier, AAFA and OPC hydration are wholly different processes. Fly ash reactivity is based on the alkaline dissolution of disordered aluminosilicate networks. A large fraction of fly ash particles is characterized by a peculiar morphology: spheres that may or may not house other smaller spheres. The material consists of a vitreous phase with a few minority crystals such as quartz ( $5 \%$ to $13 \%)$, mullite ( $8 \%$ to $14 \%$ ), hematite/magnetite ( $3 \%$ to $10 \%)$ and, on occasion, corundum or lime $[49,50]$.

In 2005, Fernández and Palomo [7] proposed a conceptual model for the alkaline activation of fly ash (see Figure 3). The process would begin with a chemical attack on the ash surface, resulting in the formation of small cavities in the walls of the ash particles, exposing the tiny particles on the inside to the action of the alkalis. In this stage of the reaction the alkalis would attack from inside and outside the particles (Figure 3b). The ash would continue to dissolve and the reaction products generated inside and outside the ash crust would precipitate, covering the smaller unreacted spheres and hindering their contact with the alkaline solution (Figure 3c). Alkaline activation would ultimately continue slowly, for once the ash particles are covered by the reaction products, alkaline attack would take place via diffusion only. At the end of the process, a number of morphologies may co-exist in the same paste: Unreacted ash particles, particles under alkaline attack and reaction products $(\mathrm{N}-\mathrm{A}-\mathrm{S}-\mathrm{H}$ gel or zeolites). This model is normally applied to the aforementioned 'cenospheres' (hollow particles or particles housing smaller spheres), which account for around 30\% of the total. All the other particles, which are solid 'plerospheres' [51], exhibit greater or lesser reactivity depending on their size. The smallest particles (under one micrometre, approximately $10 \%$ of the total) dissolve rapidly in a highly alkaline medium. Despite these rather low percentages, the speedy setting and high early age strength attained with alkaline activation can be largely explained by the intense reactivity of cenospheres and small plerospheres.

Glukhovsky [52] was the first to propose a general nano-scale mechanism for alkali activation reactions in aluminosilicate materials. His model is based essentially on dissolution-precipitation. The process begins when a series of silica and alumina monomers are released into the medium as a result of the rupture of $\mathrm{Si}-\mathrm{O}-\mathrm{Si}$ and $\mathrm{Si}-\mathrm{O}-\mathrm{Al}$ bonds attendant upon the dissolution of a source of aluminosilicate. The silica monomers inter-react to form dimers, which then react with other silica or alumina monomers to form trimers, and so on. As polymerization advances, a gel consisting in a complex aluminosilicate grid precipitates. The alkaline ion compensates the charge deficit stemming from the replacement of $\mathrm{Si}^{4+}$ with $\mathrm{Al}^{3+}$. In the very short term (minutes to hours), the gel formed has a fairly high $\mathrm{Al}$ content as a result of the high $\mathrm{Al}^{3+}$ ion concentration in the alkaline medium: reactive aluminum dissolves more quickly than reactive silicon because $\mathrm{Al}-\mathrm{O}$ bonds are inherently weaker than $\mathrm{Si}-\mathrm{O}$ bonds. As the reaction progresses, more $\mathrm{Si}-\mathrm{O}$ groups dissolve, raising the silicon concentration in the reaction medium and enhancing its uptake in the gel. The $\mathrm{N}-\mathrm{A}-\mathrm{S}-\mathrm{H}$ gel formed in hardened pastes is XRD amorphous and has been labeled as a zeolite precursor [7]. 
The structure of the N-A-S-H gel differs substantially from the $\mathrm{C}-\mathrm{S}-\mathrm{H}$ gel formed in OPC hydration. These N-A-S-H gels are characterized by a three-dimensional structure in which the $\mathrm{Si}$ is found in a variety of environments, with a predominance of $\mathrm{Q}^{4}(3 \mathrm{Al})$ and $\mathrm{Q}^{4}(2 \mathrm{Al})$ units. The silicate and aluminate groups are tetrahedrally coordinated and joined by oxygen bonds. The negative charge on tetrahedrally coordinated $\mathrm{Al}$ is offset by the presence of the alkaline cation provided by the activator used (typically $\mathrm{Na}^{+}$).

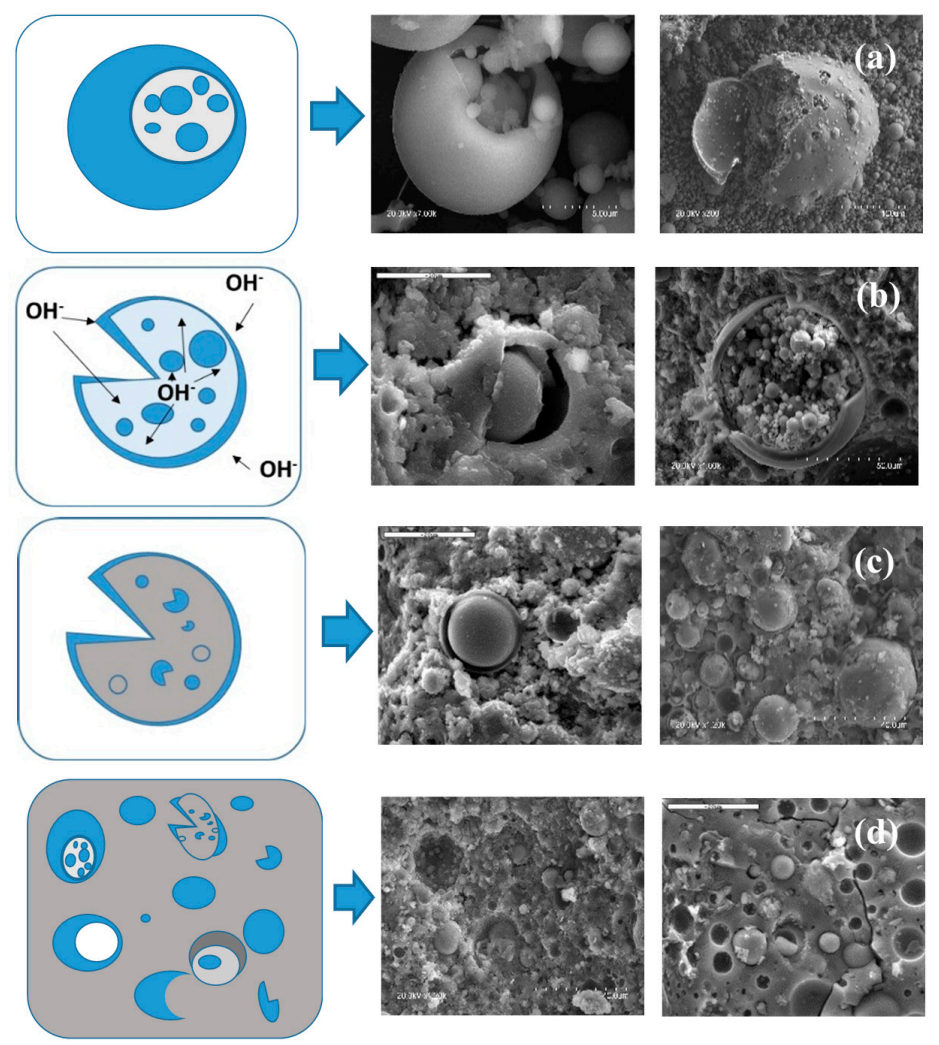

Figure 3. Conceptual model for AAFA cement hydration. (a) Starting material; (b) initial alkaline attack on the ashes and early N-A-S-H gel formation; (c) gel polymerisation and positioning on the inner and outer surfaces of the exposed fly ash; and (d) mature and heterogeneous AAFA cement paste microstructure (adapted from Fernández and Palomo [7]).

\section{Hybrid Alkaline Cement Hydration}

In recent studies, the authors have explored the potential for combining OPC and AAFA systems to form what might be called 'hybrid alkaline cements'. In these systems, the starting solid comprises small percentages (20 wt \% to $30 \mathrm{wt} \%$ ) of OPC or OPC clinker and large proportions (70 wt \% to $80 \mathrm{wt} \%$ ) of fly ash. They also contain a separate source of alkali. The most significant differences between these systems and pozzolanic cements lie in the proportion of OPC, the prevalent solid component in the latter, and the alkaline addition in the former. The pozzolanic reaction involving fly ash particles is known to be slow in pozzolanic cements, while fly ash reactivity kinetics are much faster in hybrid alkaline cements (particularly as regards the cenospheres and the smallest plerospheres).

In 2007, Palomo et al. [18] showed that according to the ${ }^{29} \mathrm{Si}$ NMR findings for alkaline fly ash cement pastes, hydration in an $\mathrm{NaOH}$ medium significantly inhibited the calcium silicate clinker phase hydration and hence portlandite formation in the first 28 days. That notwithstanding, their 28-day compressive strength was similar to blended cement strength. FTIR spectra for the NaOH-hydrated paste exhibited several new absorption bands in the $960 \mathrm{~cm}^{-1}$ to $1050 \mathrm{~cm}^{-1}$ region, attributed to a combination of N-A-S-H- and C-S-H gels. That was supported by a predominant, clearly defined peak at $-86 \mathrm{ppm}$ on the ${ }^{29} \mathrm{Si} \mathrm{NMR}$ spectra for $\mathrm{NaOH}$-activated hybrid cements (see Figure 4). Signals 
in that region may be indicative of $\mathrm{Q}^{2}(0 \mathrm{Al})$ environments typical of $\mathrm{C}-\mathrm{S}-\mathrm{H}$ gel $[47,53,54]$ as well as $\mathrm{Q}^{3}(3 \mathrm{Al})$ and $\mathrm{Q}^{4}(4 \mathrm{Al})$ environments typical of $\mathrm{N}-\mathrm{A}-\mathrm{S}-\mathrm{H}$ gels $[32,55]$. The intensification of the $-86 \mathrm{ppm}$ signal in $\mathrm{NaOH}$-hydrated pastes was attributed to the additional $\mathrm{Q}^{3}$ or $\mathrm{Q}^{4}$ environments, or both, induced by the alkaline activation of fly ash particles.

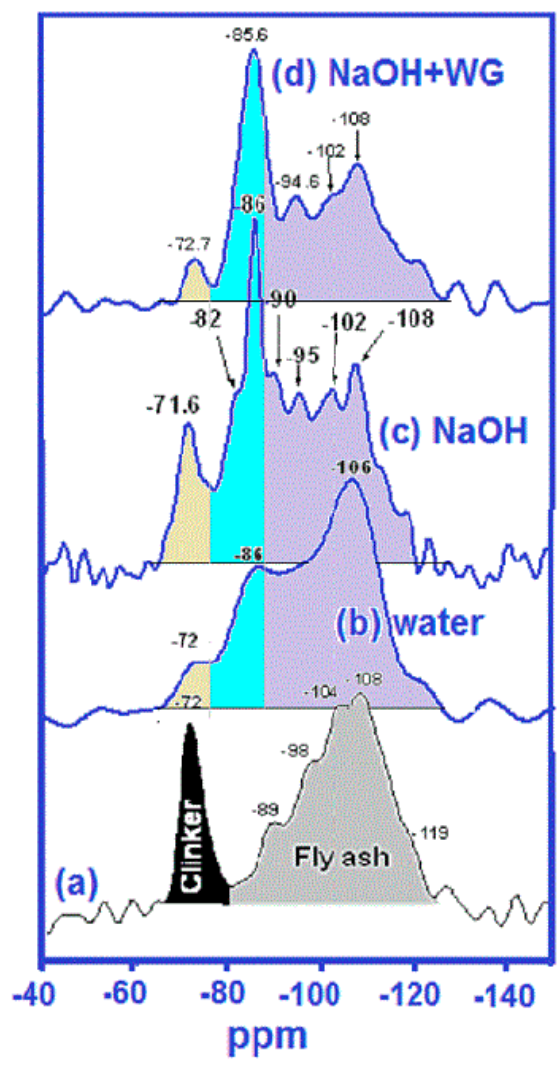

Figure 4. ${ }^{29} \mathrm{Si}$ MAS NMR spectra: (a) initial raw mix $(30 \%$ clinker $+70 \%$ fly ash); (b) 28-day water-hydrated material; (c) 28-day $\mathrm{NaOH}$-hydrated material; (d) 28-day $\mathrm{NaOH}+\mathrm{WG}$ (waterglass)-hydrated material (adapted from Palomo et al. [18]).

The co-existence of these gels must be borne in mind when studying hybrid alkaline cements. Both N-A-S-H- and C-S-H gels, whose morphologies differ, have been observed in alkali-activated metakaolin/slag mixes [56]. The $\mathrm{Ca} / \mathrm{Si}$ ratio in the $\mathrm{C}-\mathrm{S}-\mathrm{H}$ regions was around 1.0, a value significantly lower than found in the $\mathrm{C}-\mathrm{S}-\mathrm{H}$ gels forming in OPC hydration. In a later study on metakaolin/ground granulated blast furnace slag (MK/GGBFS), the aforementioned authors concluded that $\mathrm{C}-\mathrm{S}-\mathrm{H}$ gel stability declined when the activator was overly alkaline $(>7.5 \mathrm{M} \mathrm{NaOH})$. As a result, larger amounts of the Ca-containing component (GGBFS) were needed for the C-S-H regions to be detected [57]. Those findings were generally consistent with the conclusions of an earlier study on $\mathrm{MK}$ and $\mathrm{Ca}(\mathrm{OH})_{2}$ mixes by Alonso et al., in which C-S-H hydration was favored to some extent in a $5 \mathrm{M} \mathrm{NaOH}$, but not in a $12 \mathrm{M} \mathrm{NaOH}$ medium $[58,59]$.

Studies using synthetic gel phases have provided much valuable information [60-62]. Garcia-Lodeiro et al. [60] showed that the $\mathrm{Ca} / \mathrm{Si}$ ratio in $\mathrm{C}-\mathrm{S}-\mathrm{H}$ gels declined in high alkaline media. Those authors also observed that when $\mathrm{C}-\mathrm{S}-\mathrm{H}$ gel was exposed to both an alkali and soluble $\mathrm{Al}$, it evolved into a more highly polymerized $\mathrm{C}-\mathrm{A}-\mathrm{S}-\mathrm{H}$ gel [62]. In studies on mixes of synthetic $\mathrm{C}-\mathrm{S}-\mathrm{H}$ and $\mathrm{N}-\mathrm{A}-\mathrm{S}-\mathrm{H}$ gels, the same group reported that at $\mathrm{pH}>12$ the system ultimately tended toward the most stable product, C-A-S-H gel [63]. That tendency was recently confirmed in actual hybrid alkaline fly ash cements hydrated for up to one year [20]. 
The BSEM (Backscattering electron microscopy) images of several hybrid alkaline cement samples $[20,22,64-67]$ in Figure 5 illustrate this process. In the presence of the alkali $(\mathrm{NaOH})$, substantial amounts of N-A-S-H gel, along with smaller quantities of C-S-H gel, would be expected to form at early ages. With the decline in liquid phase alkalinity as a result of both carbonation and the alkaline hydrolysis of vitreous fly ash phases, $\mathrm{C}-\mathrm{S}-\mathrm{H}$ gel stability rises. As significant amounts of soluble $\mathrm{Al}$ are released by the fly ash, however, $\mathrm{C}-\mathrm{A}-\mathrm{S}-\mathrm{H}$ prevails over $\mathrm{C}-\mathrm{S}-\mathrm{H}$ formation. The generation of a pure $\mathrm{N}-\mathrm{A}-\mathrm{S}-\mathrm{H}-\mathrm{like}$ gel is unlikely in fly ash activation in hybrid alkaline cements, for the clinker present would release much more $\mathrm{Ca}$ than found in clinker-free pure AAFA cements. The outcome would be the partial replacement of the $\mathrm{Na}^{+}$ions by $\mathrm{Ca}^{2+}$ ions as charge balancers, forming what might be labeled an $(\mathrm{N}, \mathrm{C})-\mathrm{A}-\mathrm{S}-\mathrm{H}$ gel. Co-precipitation of the two types of gels has been confirmed in such systems [60-63].
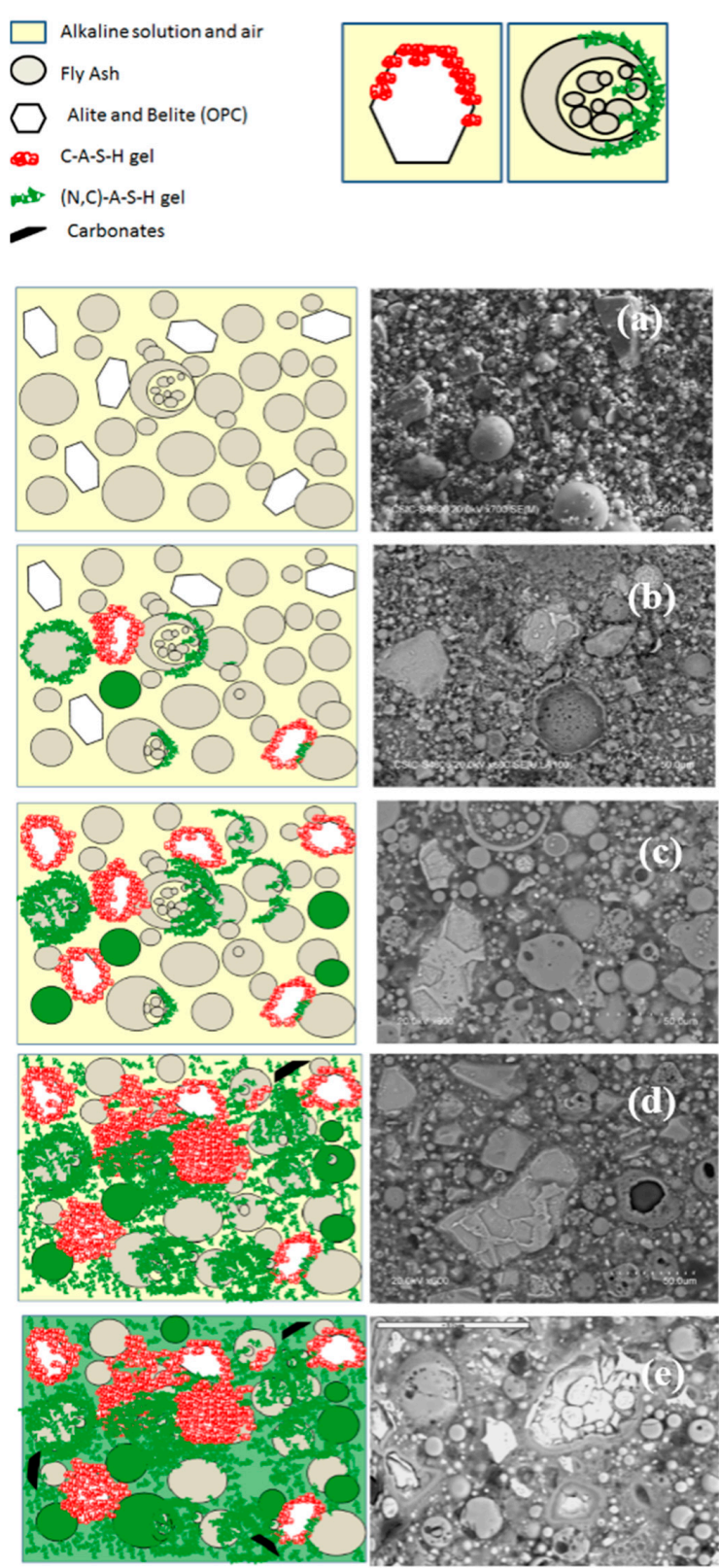

Figure 5. Changes in gel composition and microstructure of a hybrid alkaline cement with a very high fly ash content: (a) initial stage; (b) early age sample ( $\mathrm{min}) ;(\mathbf{c})$ early age sample (h); (d) 7-day sample; (e) 28-day sample. 
The use of activators with different degrees of alkalinity has a direct impact on reaction kinetics. The addition of highly alkaline activators favors ash [67] over clinker [68,69] dissolution, whereas in moderately alkaline media clinker hydration is favored and ash dissolution retarded. With time, however, the main reaction products detected are the ones most thermodynamically stable, irrespective of the type of activator used. In hybrid systems with high ash and low OPC contents the result is a mix of C-A-S-H + (N,C)-A-S-H gels [20,22,64-66].

Garcia-Lodeiro et al. [22] used isothermal conduction calorimetry in an initial study on early age (72 h) reaction kinetics in a 100\% OPC systems, 100\% FA systems and in hybrid cement consisting of $30 \%$ OPC and $70 \%$ fly ash. To that end, they used two activating solutions: $\mathrm{Na}_{2} \mathrm{CO}_{3}$ and a mix of $\mathrm{NaOH}+\mathrm{Na}_{2} \mathrm{SiO}_{3}$. Further to the data from several analytical techniques (BSEM, FTIR, DTA/TG, etc.), they concluded several things; (i) the presence of high alkali content-induced delays in normal Portland cement hydration; (ii) the presence of alkalis induced some degree of fly ash dissolution, this process is very slow at ambient temperature; (iii) Alkaline activators must be present to stimulate hybrid cement hydration. The hydration kinetics were substantially modified by the type of alkaline activator, particularly with respect to the secondary phases generated. The main reaction products, however, a mix of $\mathrm{C}-\mathrm{A}-\mathrm{S}-\mathrm{H}$ and $(\mathrm{N}, \mathrm{C})-\mathrm{A}-\mathrm{S}-\mathrm{H}$ gels, were unaffected by the activator. While the type of alkaline activator impacted reaction kinetics and the formation of secondary reaction products (carbonates, AFm phases, etc.) significantly, it did not appear to have any material effect on the main cementitious gels formed $(\mathrm{N}, \mathrm{C})-\mathrm{A}-\mathrm{S}-\mathrm{H} / \mathrm{C}-\mathrm{A}-\mathrm{S}-\mathrm{H})$.

The thermodynamically stable majority product was a mix of cementitious gels that formed irrespective of the activator used. The use of $\mathrm{Na}_{2} \mathrm{CO}_{3}$ as an alkaline activator retarded gel precipitation, favoring the formation of secondary phases such as gaylussite and AFm-type species. Nonetheless, a larger proportion of gel phase appeared to precipitate than in the system activated with the solution containing $\mathrm{NaOH}+$ WG. Similar conclusions have been obtained by different authors $[64,65,70]$ for alkali activated hybrid cements, but using solid activators [71].

${ }^{29} \mathrm{Si}$ and ${ }^{27} \mathrm{Al}$ NMR, together with TEM/EDX studies of hybrid alkaline cements hydrated for up to 1 year have shown that both $\mathrm{C}-\mathrm{S}-\mathrm{H}$ and N-A-S-H gels evolve toward cross-linked $\mathrm{C}-\mathrm{A}-\mathrm{S}-\mathrm{H}$ gels. The authors found that the lack of sufficient total $\mathrm{Ca}$ in the paste prevented conversion of all the $\mathrm{N}-\mathrm{A}-\mathrm{S}-\mathrm{H}$ to $\mathrm{C}-\mathrm{A}-\mathrm{S}-\mathrm{H}$ gel [20]. The expected nano-structural gel evolution (based on prior studies [20]) is illustrated in Figure 6. The process begins with the dissolution of the source of silicoaluminates and calcium silicates in the alkaline solution, with the concomitant release of a wide variety of dissolved species (Figure 6a). The medium becomes saturated with ions that are not uniformly distributed but rather exhibit local concentrations of the various species, depending on the nature of the nearest particle [20].

When these local concentrations reach saturation, $\mathrm{C}-\mathrm{S}-\mathrm{H}$ and $\mathrm{N}-\mathrm{A}-\mathrm{S}-\mathrm{H}$ gels precipitate simultaneously (competitive reactions), although which of the two precipitates more rapidly has yet to be determined (Figure $6 \mathrm{~b}$ ). As the reaction progresses, more $\mathrm{Si}-\mathrm{O}$ groups dissolve out of the initial aluminosilicate (fly ash) and the calcium silicate in the cement, raising the silicon concentration in the reaction medium and with it silicon uptake in both gels (Figure 6c).

At the same time, the $\mathrm{Ca}^{2+}$ and $\mathrm{Al}^{3+}$ ions present in the aqueous solution begin to diffuse through the hardened cementitious matrix. A small number of $\mathrm{Ca}^{2+}$ ions (not taken up in the $\mathrm{C}-\mathrm{S}-\mathrm{H}$ gel) interact with the N-A-S-H gel to form an (N,C)-A-S-H gel. Given the similar ionic radius and electronegative potential in $\mathrm{Na}^{+}$and $\mathrm{Ca}^{2+}$, calcium replaces the sodium ions via ion exchange reminiscent of the mechanisms observed in clay and zeolites [61,72], maintaining the three-dimensional structure of the (N,C)-A-S-H gel [63]. Similarly, the C-S-H gel forming from the silicates in cement takes aluminum into its composition (preferably) in bridge positions $[48,73,74]$, yielding $\mathrm{C}-(\mathrm{A})-\mathrm{S}-\mathrm{H} \rightarrow \mathrm{C}-\mathrm{A}-\mathrm{S}-\mathrm{H}$ gels as the aluminum content rises (Figure $6 \mathrm{~d}$ ).

Where a sufficient store of the element is available, calcium continues to diffuse through the pores of the matrix and interact with the $(\mathrm{N}, \mathrm{C})-\mathrm{A}-\mathrm{S}-\mathrm{H}$ gel. The polarizing effect of the $\mathrm{Ca}^{2+}$ (to form $\mathrm{Si}-\mathrm{O}-\mathrm{Ca}$ bonds) distorts the $\mathrm{Si}-\mathrm{O}-\mathrm{Al}$ bonds, inducing stress and ultimately rupture. At present, two hypothesis 
can explain the ion exchange mechanisms between the different gels produced in these type of cementitious systems: (a) the replacement of one $\mathrm{Al}^{3+}$ and one $\mathrm{Na}^{+}$by two $\mathrm{Ca}^{2+}$ and (b) the replacement of two ions of $\mathrm{Na}^{+}$by one $\mathrm{Ca}^{2+}$. As the $\mathrm{N}-\mathrm{A}-\mathrm{S}-\mathrm{H}$ gel releases aluminum, less polymerized structures (C-A-S-H gels) will be formed. At the same time, that $\mathrm{C}-\mathrm{A}-\mathrm{S}-\mathrm{H}$ gel formed in previous stages will incorporate more silicon and aluminum ions in bridging positions [75] (Figure 6e). However, we also have to consider that alkalis released to the pore solution might react with unreacted fly ash, then forming more N-A-S-H gel; and this last one can interact with $\mathrm{C}-\mathrm{S}-\mathrm{H}$ gel. In summary, an import part of the original alkalis can recycle and play an important role in the subsequent alkaline activation reactions. However, with time, these alkalis will become a part of the structure of the reaction products. It means that with time (with the reaction progress), the alkaline concentration will decrease until the equilibrium stage in pore solution is achieved. This process can be very slow in comparison with the very fast initial gel formation reactions. Currently authors are studying these systems by using different techniques (NMR, Electron Microscopy and Pores Solution Analysis) in order to confirm our hypothesis at long term (we are working with samples older than three years).

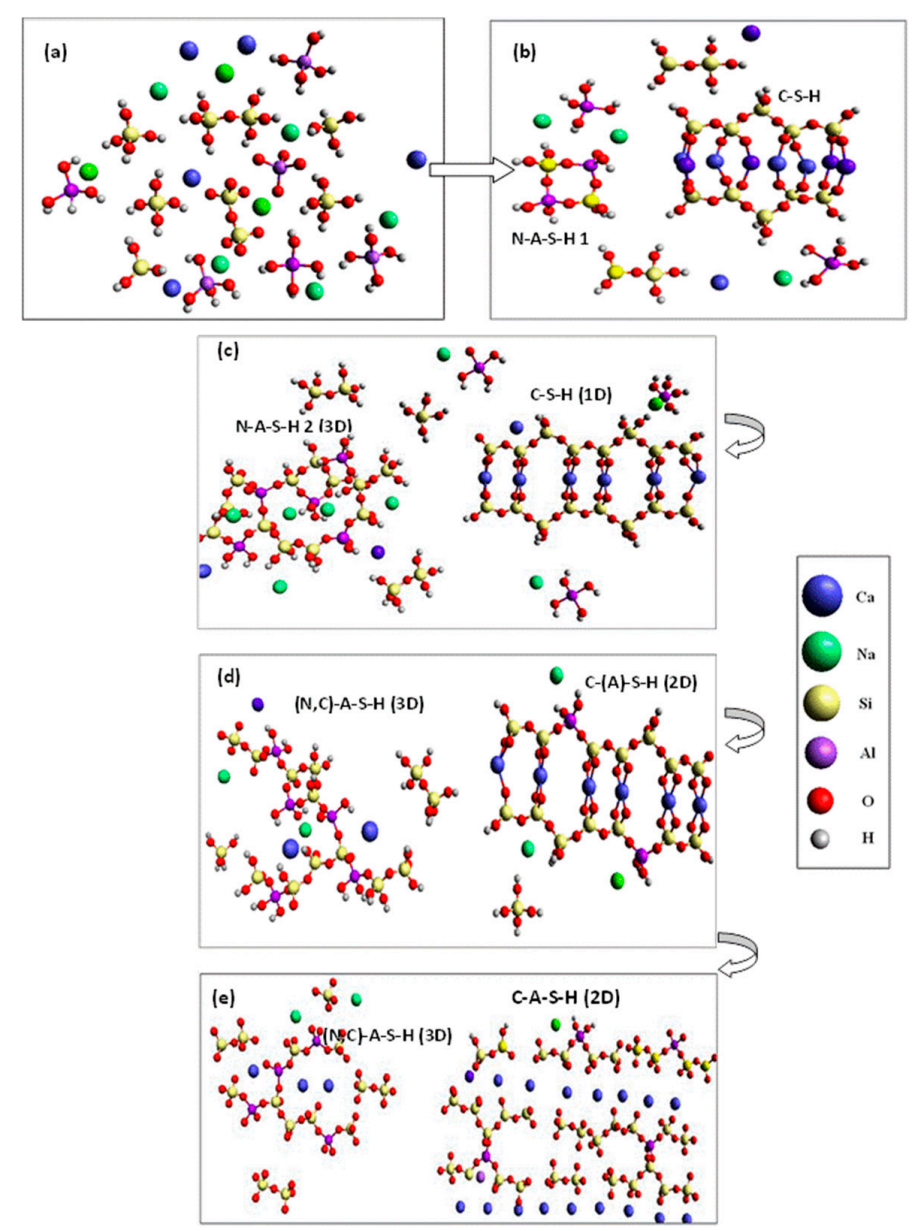

Figure 6. Nano-structural mechanism for gel formation in hybrid alkaline cements; (a) dissolution of ionic species from the source of alumino-and calcium silicates; (b) precipitation of aluminum-high (type I) N-A-S-H gels and C-S-H gels; (c) silica uptake by both gels with an increase in C-S-H gel mean chain length and the generation of silica-high type $2 \mathrm{~N}-\mathrm{A}-\mathrm{S}-\mathrm{H}$ gels; (d) diffusion of aluminum and calcium in the matrix and their uptake, respectively, in C-S-H and N-A-S-H gels to form (N,C)-A-S-H gels; (e) distortion of the $(\mathrm{N}, \mathrm{C})-\mathrm{A}-\mathrm{S}-\mathrm{H}$ gel due to the polarizing effect of calcium, leading to its rupture, while the $\mathrm{C}-\mathrm{A}-\mathrm{S}-\mathrm{H}$ gel continues to take up aluminum species in bridging positions, favoring chain cross-linking and hence a more polymerized structure (hydrogen bonds omitted in this final stage). 
With time and under equilibrium conditions (attainable after longer reaction times), a (N)-C-A-S-H gel prevails. This is consistent with the behavior observed by the same authors in synthetic samples.

In these complex cementitious blends, the products formed and their proportions depend on reaction conditions, including: the chemical composition, shape, mineralogy and particle size distribution of the prime materials (fly ash reactivity rises with its vitreous content [49] and with declining particle size [76]), as well as the alkalinity $(\mathrm{pH})$ generated by the activator $[20,22,50,64]$.

\section{Effect of Alkaline Activator in Hybrid Alkaline Cement Hydration}

Garcia-Lodeiro et al. [22], analyzing hybrid cements activated with solutions of different alkalinity, found that, while the type of alkaline activator impacted reaction kinetics and the formation of secondary reaction products (carbonates, AFm phases ... ) significantly, it did not appear to have any material effect on the main cementitious gels formed ((N,C)-A-S-H/C-A-S-H). The thermodynamically stable majority product was a mix of cementitious gels that formed irrespective of the activator used. Nonetheless, the relative amount of each gel was observed to depend on the activator. Whilst the presence of strong alkalis favored the dissolution of fly ash and the precipitation of an $(\mathrm{N}, \mathrm{C})-\mathrm{A}-\mathrm{S}-\mathrm{H}$ gel, the use of more moderately alkaline compounds favored the formation of C-A-S-H gels [22].

\subsection{Intense Activation}

The vast majority of hybrid cement hydration studies have been conducted with activators (primarily $\mathrm{NaOH}$ or mixes of $\mathrm{NaOH}+\mathrm{WG}$ ) that render the medium highly alkaline $[20,22,26,50,64]$. The high alkalinity of these solutions (with $\mathrm{pH}$ values of over 13) favors speedy ash dissolution. Moreover, at ambient temperature fly ash activation is accelerated by the presence of Portland cement clinker. The explanation for this beneficial effect lies in the heat released during cement hydration, which would favor the chemical reactions inducing ash dissolution, setting and hardening.

Highly alkaline activators, such as $\mathrm{NaOH}$, prompt the hydrolysis of $\mathrm{Si}-\mathrm{O}$ and $\mathrm{Al}-\mathrm{O}$ bonds (the $\mathrm{OH}^{-}$ions act as catalysts), while the presence of soluble silica in the form of silicate ions enhances the polymerization rate of the ionic species present in the system $[77,78]$. Portland cement hydration, in turn, is affected by alkaline content $\left(\mathrm{OH}^{-}\right.$concentration) and the presence of soluble silica $[68,69,79]$.

A number of authors have analyzed early age (1 to 28 days) hybrid cement behavior $\left(\mathrm{MK}+\mathrm{Ca}(\mathrm{OH})_{2}, \mathrm{BFS}+\mathrm{OPC}, \mathrm{FA}+\mathrm{OPC} . ..\right)$ when the material is hydrated in the presence of different concentrations of strong activators. They consistently observed that high alkalinity favors the formation of $\mathrm{N}-\mathrm{A}-\mathrm{S}-\mathrm{H} /(\mathrm{N}, \mathrm{C})-\mathrm{A}-\mathrm{S}-\mathrm{H}$ gels to the detriment of $\mathrm{C}-\mathrm{S}-\mathrm{H}$ gels and inhibits portlandite formation. C-S-H gel formation is favored by milder alkalinity $[18,22,26,56-59]$.

That the type of activator and the alkalinity generated affect reaction kinetics and the nature of the gels initially formed has been ratified by studies on later age cements [20,22]. As hydration progresses, only the most thermodynamically stable products are identified. In systems containing large proportions of fly ash and low proportions of Portland clinker the outcome is a mix of $\mathrm{C}-\mathrm{A}-\mathrm{S}-\mathrm{H}$ and $(\mathrm{N}, \mathrm{C})-\mathrm{A}-\mathrm{S}-\mathrm{H}$ gels [20]. The proportion of each gel depends on the alkaline activator, however. When a mild activator is used, $\mathrm{C}-\mathrm{A}-\mathrm{S}-\mathrm{H}$ gels are generated, with a minority presence of $(\mathrm{C}, \mathrm{N})-\mathrm{A}-\mathrm{S}-\mathrm{H}$ gels.

Some of the arguments against the use of pure alkali-activated cements have centered on practical health and safety issues around the preparation and storage of highly alkaline solutions on construction factory sites. Given that alkali-activated cements are often touted as low- $\mathrm{CO}_{2}$ alternatives to $\mathrm{PC}$, the associated $\mathrm{CO}_{2}$ footprint of the alkali activators has come under scrutiny [80]. The manufacture of $\mathrm{NaOH}$ and $\mathrm{Na}_{2} \mathrm{SiO}_{3}$ are fairly energy intensive processes. As a general rule of thumb, Duxson et al. [81] contended that the $\mathrm{CO}_{2}$ footprint of manufactured $\mathrm{NaOH}$ and $\mathrm{Na}_{2} \mathrm{SiO}_{3}$ stands at around $1 \mathrm{t} \mathrm{CO} / \mathrm{t}$. Furthermore, in hybrid alkaline systems, highly alkaline activators appear to adversely affect $\mathrm{C}-\mathrm{S}-\mathrm{H}$ 
gel stability, the kinetics of clinker calcium silicate hydration or both. The result has been a growing interest in 'just add water' hybrid alkaline cement formulations, in which milder alkalis are used.

\subsection{Mild Activation}

The mildly alkaline activators commonly used to hydrate these hybrid cements include weak (sodium carbonate) and strong (sodium sulfate) acidic salts (see Table 1). Whilst $\mathrm{NaOH}$ solutions generate $\mathrm{pH}$ values ranging from 13 to 14 , the media containing these milder activators exhibit values from 7 to 13 .

The effect of such soluble salts in raising the $\mathrm{pH}$ in the medium may possibly be attributed to their synergetic reaction with $\mathrm{Ca}(\mathrm{OH})_{2}[17,71,82]$, further to Equation (1):

$$
x \mathrm{Ca}(\mathrm{OH})_{2}+\mathrm{A}_{x} \mathrm{~B}_{y} \leftrightarrow \mathrm{Ca}_{x} \mathrm{~B}_{2}(\mathrm{~s})+2 x \mathrm{~A}(\mathrm{OH})(\mathrm{ac})
$$

where $A$ is an alkaline cation, normally $\mathrm{Na}^{+}$or $\mathrm{K}^{+}$, and $B$ is the anion in the respective inorganic salt. Alkalinity is raised provided that the anion in the inorganic salt used forms an insoluble calcium compound $\left(\mathrm{Ca}_{x} \mathrm{~B}_{2}\right)$, shifting equilibrium to the right in Equation (1).

The inorganic salts most widely used are listed in Table 1, along with their solubility products and the equilibrium calcium concentration. Lower calcium ion concentrations favor the precipitation of the inorganic calcium salt $\left(\mathrm{Ca}_{x} \mathrm{~B}_{2}\right)$ generated, shifting equilibrium further to the right and rendering the activator more effective.

Table 1. Solubility (g of solute/100 $\mathrm{g}$ of water) and the Solubility Product Constants, $\mathrm{K}_{\mathrm{sp}}$ of sodium and respective calcium salts and equilibrium calcium concentration (Equation (1)).

\begin{tabular}{|c|c|c|c|c|c|}
\hline \multirow{2}{*}{ A = Anión } & \multicolumn{2}{|c|}{ Na Salts } & \multicolumn{3}{|c|}{ Ca Salts } \\
\hline & $\begin{array}{l}\text { Solubility g/100 g of } \\
\text { Water Near to } 25^{\circ} \mathrm{C}\end{array}$ & Ksp & $\begin{array}{l}\text { Solubility g/100 g of } \\
\text { Water Near to } 25^{\circ} \mathrm{C}\end{array}$ & Ksp & $\left(\mathrm{Ca}^{2+}\right)$ \\
\hline $\mathrm{OH}^{-}$ & 100 & 110 & 0.160 & $5.5 \times 10^{-6}$ & 11.1 \\
\hline $\mathrm{F}^{-}$ & 4.13 & - & 0.0016 & $5.3 \times 10^{-9}$ & 1.1 \\
\hline $\mathrm{CO}_{3}{ }^{2-}$ & 30.7 & 1.2 & 0.00066 & $2.8 \times 10^{-9}$ & 0.053 \\
\hline $\mathrm{SO}_{4}^{2-}$ & 28.1 & 10.3 & 0.205 & $9.1 \times 10^{-6}$ & 3.0 \\
\hline $\mathrm{PO}_{4}{ }^{2-}$ & 14.5 & 2.24 & 0.00012 & $2.0 \times 10^{-29}$ & 0.019 \\
\hline
\end{tabular}

Another advantage of inorganic salts over highly alkaline activators (such as $\mathrm{NaOH}$ and $\mathrm{WG}$ ) is that they have a lower impact on the hydration reaction of the clinker component in hybrid cements. In these systems, the clinker must first react with water to generate portlandite ( $\mathrm{pH} \sim 12.5$ ), which then reacts with the inorganic salt to generate the respective insoluble calcium salt and $\mathrm{Na}^{+}(\mathrm{OH})^{-}$: i.e., alkalinity is generated in situ, as indicated in Equation (1) $(\mathrm{pH}>13)$. For instance, depending on whether the activator is a carbonate or a sulfate, its reaction with $\mathrm{Ca}(\mathrm{OH})_{2}$ yields calcium carbonate or hydrated calcium sulfate (possibly gypsum), as shown in Equations (2) and (3), as well as $\mathrm{Na}^{+}(\mathrm{OH})^{-}$(aq.), thereby raising medium alkalinity. In addition, the heat released during initial OPC hydration favors and expedites the dissolution of supplementary cementitious materials at high $\mathrm{pH}[17,71,82]$.

$$
\begin{gathered}
\mathrm{Ca}(\mathrm{OH})_{2}+\mathrm{Na}_{2} \mathrm{CO}_{3} \rightarrow \mathrm{CaCO}_{3}(\mathrm{~s})+\mathrm{Na}^{+} \mathrm{OH}^{-} \text {(aq.) } \\
\mathrm{Ca}(\mathrm{OH})_{2}+\mathrm{Na}_{2} \mathrm{SO}_{4} \rightarrow \mathrm{CaSO}_{4} \cdot 2 \mathrm{H}_{2} \mathrm{O}(\mathrm{s})+\mathrm{Na}^{+} \mathrm{OH}^{-} \text {(aq.) }
\end{gathered}
$$

Another intrinsic factor in the use of inorganic salts as mildly alkaline activators is the role of the constituent anion, particularly in connection with the secondary phases precipitating in these systems. The use of $\mathrm{Na}_{2} \mathrm{CO}_{3}$ as an activator, for instance, has been shown to favor the formation of gaylussite-like carbonates and calcite at very early reaction times $(2 \mathrm{~h})$ [22]. In that study, gaylussite was shown to be metastable during alkaline fly ash cement hydration. The authors hypothesized 
that the temporary uptake of $\mathrm{Na}$ in precipitating gaylussite delays the alkali activation of glassy fly ash phases.

When in a subsequent study $\mathrm{Na}_{2} \mathrm{SO}_{4}$ was used to activate cements, no ettringite was observed at any of the ages analyzed [64]. As the OPC used in these systems is normally blended with gypsum, it should theoretically have been able to form ettringite. Even in studies on pure OPC, however, the presence of alkalis has been shown to prevent ettringite formation $[68,69]$, favoring instead other $\mathrm{C}_{3} \mathrm{~A}$ hydration products such as phase $\mathrm{U}[83,84]$. Monocarboaluminate $\left(\mathrm{Ca}_{4} \mathrm{Al}_{2} \mathrm{CO}_{3} \cdot 11 \mathrm{H}_{2} \mathrm{O}\right)$ has been observed to be the prevalent in seven-day product. Systems with carbonate-containing activators exhibit the same behavior [22]: No ettringite is detected, although AFm (hemi and monocarboaluminate) forms in the seven-day materials.

Alahrache et al. [70] analyzed the effect of other, less conventional, mildly alkaline activators such as potassium citrate, sodium-potassium silicate and sodium oxalate on hydration kinetics and strength development in systems with high fly ash and low OPC contents. They found that the two latter activators were promising candidates for activation, for they shortened setting time and raised early age mechanical strength. The use of potassium citrate, however, retarded ash and clinker hydration, due either to the formation of complexes on the surfaces of these particles or to the hampering of C-A-S-H gel and AFm phase formation.

In a summary, the type of activator used has a direct impact on the secondary products precipitating and on reaction kinetics (essentially through the $\mathrm{pH}$ generated in the medium), accelerating or retarding the precipitation of the main reaction products. Irrespective of the type of activator used, however, the majority and most thermodynamically stable product in these non-equilibrium systems with limited amounts of calcium is a mix of cementitious gels. The proportion of each gel in the mix does, however, depend on the alkalinity generated in the medium.

\section{Conclusions}

This paper presents descriptive models for high fly ash-content hybrid alkaline cement hydration, a process that involves aspects typical of both PC and AAFA cement hydration. Hybrid binders arouse considerable interest given that their use would reduce $\mathrm{CO}_{2}$ emissions to much lower levels than traditional fly ash pozzolanic cements.

In hybrid cements activated directly with highly alkaline chemicals $(\mathrm{NaOH})$, the prevalence of $\mathrm{N}-\mathrm{A}-\mathrm{S}-\mathrm{H}$ gel interferes with the normal hydration of the calcium silicate phases present in the clinker, thereby hindering $\mathrm{C}-\mathrm{S}-\mathrm{H}$ gel formation. Both $\mathrm{Al}$ and $\mathrm{Na}$ have been shown to favor the conversion of C-S-H gel to C-A-S-H-like gel. Conversely, the presence of Ca attributable to clinker hydration has been shown to modify the structure of the $\mathrm{N}-\mathrm{A}-\mathrm{S}-\mathrm{H}$ gel formed during fly ash hydration, with the appearance of an (N,C)-A-S-H structure.

In hybrid blends activated indirectly with moderately alkaline compounds (such as alkaline sulphates, carbonates or phosphates), both N-A-S-H and C-S-H gels are observed to form at early ages. The initial rapid hydration of the calcium silicate present in the clinker generates sufficient $\mathrm{Ca}$ and alkalinity to convert part of the soluble alkaline salts to $\mathrm{NaOH}$, which then activates the glassy phases in the fly ash, inducing paste setting. The role of the anion in soluble alkaline salt activators should not be underestimated.

In hybrid alkaline cement systems, both $\mathrm{N}-\mathrm{A}-\mathrm{S}-\mathrm{H}-$ and $\mathrm{C}-\mathrm{S}-\mathrm{H}$ gels have been proven to evolve toward $\mathrm{C}-\mathrm{A}-\mathrm{S}-\mathrm{H}$ structures in older age specimens. Depending on the total amount of available $\mathrm{Ca}$, a fraction of the $\mathrm{N}-\mathrm{A}-\mathrm{S}-\mathrm{H}$ gel may remain in the system indefinitely.

Acknowledgments: This study was funded by a research grant (BIA2013-43293-R) awarded by the Spanish Ministry of the Economy and Competitiveness (MINECO) to Ana Fernández. The participation of Post-graduate Studies Council post-doctoral grantees (2011) Shane Donatello and Ines Garcia-Lodeiro (JAE Doc 2011) was co-funded by MINECO and the European Social Fund. 
Author Contributions: Ángel Palomo conceived and designed the experiments; Shane Donatello and Inés Garcia-Lodeiro performed the experiments; Inés Garcia-Lodeiro and Ana Fernández-Jiménez analyzed the data; all authors have contributed in the writing of the paper.

Conflicts of Interest: The authors declare no conflict of interest. The founding sponsors had no role in the design of the study; in the collection, analyses, or interpretation of data; in the writing of the manuscript, and in the decision to publish the results.

\section{References}

1. Sharp, J.H.; Gartner, E.M.; Macphee, D.E. Novel cement systems (sustainability). Session 2 of the Fred Glasser Cement Science Symposium. Adv. Cem. Res. 2010, 22, 195-202. [CrossRef]

2. Malhotra, V.M.; Mehta, P.K. Pozzolanic and Cementitious Materials. In Advances in Concrete Technology; Taylor and Francis: Oxon, UK, 1996.

3. Massazza, F. Pozzolanic Cements. Cem. Concr. Compos. 1993, 15, 185-214. [CrossRef]

4. Palomo, A.; Grutzeck, M.W.; Blanco, M.T. Alkali-activated fly ashes. A cement for the future. Cem. Concr. Res. 1999, 29, 1323-1329. [CrossRef]

5. Shi, C.; Krivenko, P.V.; Roy, D.M. Alkali-Activated Cements and Concretes; Taylor and Francis: New York, NY, USA, 2006.

6. Duxson, P.; Fernández-Jiménez, A.; Provis, J.L.; Lukey, G.C.; Palomo, A.; van Deventer, J.S.J. Geopolymer technology: The current state of the art. J. Mater. Sci. 2007, 42, 2917-2933. [CrossRef]

7. Fernández-Jiménez, A.; Palomo, A. Composition and microstructure of alkali activated fly ash binder: Effect of the activator. Cem. Concr. Res. 2005, 35, 1984-1992. [CrossRef]

8. Criado, M.; Fernández-Jiménez, A.; Palomo, A. Alkali activation of fly ash: Effect of the $\mathrm{SiO}_{2} / \mathrm{Na}_{2} \mathrm{O}$ ratio. Part I: FTIR study. Microporous Mesoporous Mater. 2007, 106, 180-191. [CrossRef]

9. Duxson, P.; Mallicoat, S.W.; Lukey, G.C.; Kriven, W.M.; van Deventer, J.S.J. The effect of alkali and Si/Al ratio on the development of mechanical properties of metakaolin-based geopolymers. Colloids and Surfaces A: Physicochem. Eng. Asp. 2007, 292, 8-20. [CrossRef]

10. Fernández-Jiménez, A.; Palomo, A. Factors affecting early compressive strength of alkali activated fly ash (OPC-free) concrete. Mater. Constr. 2007, 57, 7-22.

11. Cement Composition; European standards EN 197-1; Europena Committee for Standardization: Brussels, Belgium, 2000.

12. Donatello, S.; Tyrer, M.; Cheeseman, C.R. Comparison of test methods to assess pozzolanic activity. Cem. Concr. Compos. 2010, 32, 121-127. [CrossRef]

13. McCarthy, M.J.; Dhir, R.K. Development of high volume fly ash cements for use in concrete construction. Fuel 2005, 84, 1423-1432. [CrossRef]

14. De Weerdt, K.; Kjellsen, K.O.; Sellevold, E.; Justnes, H. Synergy between fly ash and limestone powder in ternary cements. Cem. Concr. Compos. 2011, 33, 30-38. [CrossRef]

15. Bentz, D.P.; Sato, T.; de la Varga, I.; Jason Weiss, W. Fine limestone additions to regulate setting in high volumen fly ash mixtures. Cem. Concr. Compos. 2012, 34, 11-17. [CrossRef]

16. Shi, C.; Day, R.L. Pozzolanic reaction in the presence of chemical activators Part II: Reaction products and mechanism. Cem. Concr. Res. 2000, 30, 607-613. [CrossRef]

17. Zhang, Y.M.; Sun, W.; Yan, H.D. Hydration of high-volume fly ash cement pastes. Cem. Concr. Compos. 2000, 22, 445-452. [CrossRef]

18. Palomo, A.; Fernández-Jiménez, A.; Kovalchuk, G.; Ordonez, L.M.; Naranjo, M.C. OPC-fly ash cementitious systems: Study of gel binders produced during alkaline hydration. J. Mater. Sci. 2007, 42, 2958-2966. [CrossRef]

19. Shi, C.; Fernández-Jiménez, A.; Palomo, A. New cements for 21st century: The Pursuit of an alternative to Portland Cement. Cem. Concr. Res. 2011, 41, 750-763. [CrossRef]

20. Garcia-Lodeiro, I.; Fernández-Jiménez, A.; Palomo, A. Variation in hybrid cements over time. Alkaline activation of fly ash-portland cement blends. Cem. Concr. Res. 2013, 52, 112-122.

21. Fernández-Jiménez, A.; Zibouche, F.; Boudissa, N.; García-Lodeiro, I.; Abadlia, M.T.; Palomo, A. "Metakaolin-Slag-Clinker Blends." The role of $\mathrm{Na}+$ or $\mathrm{K}+$ as alkaline activators of these ternary blends. J. Am. Ceram. Soc. 2013. [CrossRef] 
22. Garcia-Lodeiro, I.; Fernández-Jiménez, A.; Palomo, A. Hydration kinetics in hybrid binders: Early reaction stages. Cem. Concr. Compos. 2013, 39, 82-92. [CrossRef]

23. Gümeyisi, E.; Gesoglu, M.; Algin, Z.; Mermedas, K. Optimization of concrete mixtures with hybrid belnds of metakaolin and fly ash using response Surface method. Compos. Part B Eng. 2014, 60, 707-715. [CrossRef]

24. Abdonllahnejad, Z.; Hlvadek, P.; Miraldo, S.; Pacheco-Torgal, F.; Barroso de Aguiar, J.L. Compressive Strenght, Microstructure and Hydration Products of Hybrid Alkaline Cements. Mater. Res. 2014, 17, 829-837. [CrossRef]

25. Kang, X.; Ge, L.; Kang, G.-C.; Mathews, C. Laboratory investigation on the strength, stiffness, and thermal conductivity of fly ash and lime kiln dust stabilized clay subgrade materials. Road Mater. Pavement Des. 2015, 16, 928-945. [CrossRef]

26. Kang, X.; Ge, L.; Liao, W.C. Cement Hydration-Based Micromechanics Modelling of the Time-Dependent Small-Strain Stiffness of Fly Ash-Stabilized Soils. Int. J. Geomech. 2016, 16, 04015071. [CrossRef]

27. Taylor, H.F.W. Cement Chemistry, 2nd ed.; Thomas Telford: London, UK, 1997.

28. Scrivener, K.L.; Nonat, A. Hydration of cementitious materials, present and future. Cem. Concr. Res. 2011, 41, 651-665. [CrossRef]

29. Bullard, J.W.; Jennings, H.M.; Livingston, R.A.; Nonat, A.; Scherer, G.W.; Schweitzer, J.S.; Scrivener, K.L.; Thomas, J.L. Mechanisms of cement hydration. Cem. Concr. Res. 2011, 41, 1208-1223. [CrossRef]

30. Lothenbach, B.; Scrivener, K.; Hooton, R.D. Supplementary cementitious materials. Cem. Concr. Res. 2011, 41, 1244-1256. [CrossRef]

31. Deschner, F.; Winnefeld, F.; Lothenbach, B.; Seufert, S.; Schwesig, P.; Dittrich, S.; Goetz-Neunhoeffer, F.; Neubauer, J. Hydration of Portland cement with high replacement by siliceous fly ash. Cem. Concr. Res. 2012, 42, 1389-1400. [CrossRef]

32. Palomo, A.; Alonso, S.; Fernandez-Jimenez, A.; Sobrados, I.; Sanz, J. Alkaline activation of fly ashes: NMR study of the reaction products. J. Am. Ceram. Soc. 2004, 87, 1141-1145. [CrossRef]

33. Fernandez-Jimenez, A.; Palomo, A.; Criado, M. Microstructure development of alkali-activated fly ash cement: A descriptive model. Cem. Concr. Res. 2005, 35, 1204-1209. [CrossRef]

34. Provis, J.L. Geopolymers: Structure, Processing, Properties and Industrial Applications; CRC Press: Oxford, UK, 2009.

35. Collepardi, M.; Baldini, G.; Pauri, M.; Corradi, M. Tricalcium aluminate hydration in the presence of lime, gypsum or sodium sulphate. Cem. Concr. Res. 1978, 8, 571-580. [CrossRef]

36. Meredith, P.; Donald, A.M.; Meller, N.; Hall, C. Tricalcium aluminate hydration: Microstructural observations by in-situ electron microscopy. J. Mater. Sci. 2004, 39, 997-1005. [CrossRef]

37. Bentur, A. Effect of gypsum on the hydration and strength of $C_{3} S$ pastes. J. Am. Ceram. Soc. 1976, 59, $210-213$. [CrossRef]

38. Odler, I.; Schuppstuhl, J. Early hydration of tricalcium silicate III. Control of the induction period. Cem. Concr. Res. 1981, 11, 765-774. [CrossRef]

39. Quennoz, A.; Scrivener, K.L. Interactions between alite and $\mathrm{C}_{3} \mathrm{~A}$-gypsum hydrations in model cements. Cem. Concr. Res. 2013, 44, 46-54. [CrossRef]

40. Juilliand, P.; Gallucci, E.; Flatt, R.; Scrivener, K. Dissolution theory applied to the induction period in alite hydration. Cem. Concr. Res. 2010, 40, 831-844. [CrossRef]

41. Scrivner, K.L. The Development of the Microstructure during the Hydration of Portland Cement. Ph.D. Thesis, University of London, London, UK, 1984.

42. Gartner, E.M.; Young, J.F.; Damidot, D.A.; Jawed, I. Hydration of portland cement. In Structure and Performance of Cements, 2nd ed.; Bensted, J., Barnes, P., Eds.; Spon Press: New York, NY, USA, 2002; pp. 57-113.

43. Garrault, S.; Nonat, A. Experimental investigation of calcium silicate hydrate (C-S-H) nucleation. J. Cryst. Growth 1999, 200, 565-574. [CrossRef]

44. Chen, Y.; Odler, I. On the origin of Portland cement setting. Cem. Concr. Res. 1992, 22, 1130-1140. [CrossRef]

45. Skalny, J.; Johansen, V.; Thaulow, N.; Palomo, A. DEF: As a form of sulfate attack. Mater. Constr. 1996, 46, 5-29. [CrossRef]

46. Taylor, H.F.W.; Famy, C.; Scrivener, K.L. Delayed ettringite formation. Cem. Concr. Res. 2001, 31, $683-693$. [CrossRef]

47. Cong, X.D.; Kirkpatrick, R.J. ${ }^{29}$ NMR study of the structure of the calcium silicate hydrate. Adv. Cem. Bas. Mat. 1996, 3, 144-156. [CrossRef] 
48. Richardson, I.G. Model Structures for C-(A)-S-H. Acta Crystallogr. Sect. B Struct. Sci. Cryst. Eng. Mater. 2014, 70, 903-923. [CrossRef] [PubMed]

49. Fernández-Jiménez, A.; Palomo, A. Characterization of fly ashes. Potencial reactivity as alkaline cements. FUEL 2003, 82, 2259-2265. [CrossRef]

50. Garcia-Lodeiro, I.; Fernández-Jiménez, A.; Palomo, A. Crucial insights on the mix design of alkali-activated cement based systems. Handbook of Alkali-Activated Cements, Mortars and Concretes. Available online: http: / /dx.doi.org/10.1533/978-1-78242-288-4.1.49 (accessed on October 2015).

51. De Vargas, A.S.; Dal Molin, D.C.C.; Vilela, A.C.F.; Jalali, S.; Gomes, J.P.C. Activacão Alcalina de Cinzas Volantes Utilizando Solucão Combinada de $\mathrm{NaOH}$ e $\mathrm{Ca}(\mathrm{OH})_{2} ; 61$ Congresso Anual da ABM: Rio de Janeiro, Brasil, 2006.

52. Glukhovsky, V. Ancient, Modern and Future Concretes. In Proceedings of the First International Conference Alkaline Cements and Concretes, Kiev, Ukraine, 11-14 October 1994.

53. Grutzeck, M.; Benesi, A.; Fanning, B. Silicon 29 Magic Angle Spinning Nuclear Magnetic Resonance Study of Calcium Silicate Hydrates. J. Am. Ceram. Soc. 1989, 72, 665-678. [CrossRef]

54. Garcia-Lodeiro, I.; Fernandez-Jimenez, A.; Sobrados, I.; Sanz, J.; Palomo, A. C-S-H Gels: Interpretation of ${ }^{29}$ Si MAS-NMR Spectra. J. Am. Ceram. Soc. 2012, 95, 1440-1446. [CrossRef]

55. Criado, M.; Fernández-Jiménez, A.; Palomo, A.; Sobrados, I. Effect of the $\mathrm{SiO}_{2} / \mathrm{Na}_{2} \mathrm{O}$ ratio on the alkali-activation of fly ash. Part II: ${ }^{29}$ Si MAS-NMR survey. Micr. Mes. Mat. 2008, 109, 525-534. [CrossRef]

56. Yip, C.K.; van Deventer, J.S.J. Microanalysis of calcium silicate hydrate gel formed within a geopolymeric binder. J. Mater. Sci. 2003, 38, 3851-3860. [CrossRef]

57. Yip, C.K.; Lukey, G.C.; van Deventer, J.S.J. The coexistence of geopolymeric gel and calcium silicate hydrate at the early stage of alkaline activation. Cem. Concr. Res. 2005, 35, 1688-1697. [CrossRef]

58. Alonso, S.; Palomo, A. Alkaline activation of metakaolin and calcium hydroxide mixtures: Influence of temperature, activator concentration and solids ratio. Mater. Lett. 2001, 47, 55-62. [CrossRef]

59. Granizo, M.L.; Alonso, S.; Blanco-Varela, M.T.; Palomo, A. Alkaline activation of metakaolin: Effect of calcium hydroxide in the products of reaction. J. Am. Ceram. Soc. 2002, 85, 225-231. [CrossRef]

60. Garcia-Lodeiro, I.; Macphee, D.E.; Palomo, A.; Fernández-Jiménez, A. Effect of alkalis on fresh C-S-H gels: FTIR analysis. Cem. Concr. Res. 2009, 39, 147-153. [CrossRef]

61. Garcia-Lodeiro, I.; Fernandez-Jimenez, A.; Palomo, A.; Macphee, D.E. Effect of calcium addtiton in N-A-S-H cementitious gels. J. Am. Ceram. Soc. 2010, 93, 1934-1940.

62. Garcia-Lodeiro, I.; Fernández-Jiménez, A.; Palomo, A.; Macphee, D.E. Effect on fresh C-S-H gels of the simultaneous addition of alkali and aluminium. Cem. Concr. Res. 2010, 40, 27-32. [CrossRef]

63. Garcia-Lodeiro, I.; Palomo, A.; Fernández-Jiménez, A.; Macphee, D.E. Compatability studies between $\mathrm{N}-\mathrm{A}-\mathrm{S}-\mathrm{H}$ and C-A-S-H gels. Study in the ternary diagram $\mathrm{Na}_{2} \mathrm{O}-\mathrm{CaO}-\mathrm{Al}_{2} \mathrm{O}_{3}-\mathrm{SiO}_{2}-\mathrm{H}_{2} \mathrm{O}$. Cem. Concr. Res. 2011, 41, 923-931.

64. Donatello, S.; Fernández-Jiménez, A.; Palomo, A. Very high volumen fly ash cements: Early age hydration study using $\mathrm{Na}_{2} \mathrm{SO}_{4}$ as an activator. J. Am. Ceram. Soc. 2013, 96, 900-906. [CrossRef]

65. Donatello, S.; Maltseva, O.; Fernández-Jiménez, A.; Palomo, A. The Early Age Hydration Reactions of a Hybrid Cement Containing a Very High Content of Coal Bottom Ash. J. Am. Ceram. Soc. 2014, 97, 929-937. [CrossRef]

66. Donatello, S.; Fernández-Jiménez, A.; Palomo, A. Durability of very high volume fly ash cement pastes and mortars in aggressive solutions. Cem. Concr. Compos. 2013, 38, 12-20. [CrossRef]

67. Shi, C.; Day, R.L.D. Acceleration of the reactivity of Fly Ash by Chemical Activation. Cem. Concr. Res. 1995, 25, 15-21. [CrossRef]

68. Martinez-Ramirez, S.; Palomo, A. Microstructure studies on Portland cement pastes obtained in highly alkaline enviroments. Cem. Concr. Res. 2001, 31, 1581-1585. [CrossRef]

69. Martinez-Ramirez, S.; Palomo, A. OPC hydration with highly alkaline solutions. Ad. Cem. Res. 2001, 13, 123-129. [CrossRef]

70. Alahrache, S.; Winnefeld, F.; Champenois, J.B.; Hesselbarth, F.; Lothenbach, B. Chemical activation of hybrid binders based on siliceous fly ash and Portland cement. Cem. Concr. Compos. 2016, 66, 10-23. [CrossRef]

71. Fernández-Jiménez, A.; Sobrados, I.; Sanz, J.; Palomo, A. Hybrid cements with very low OPC content Alkaline activation of metakaolin-slag-clinker blends. In Proceedings of the 13th International Congress on the chemistry of Cement (XIII ICCC), “Cementing a Sustainable Future”, Madrid, Spain, 3-8 July 2011. 
72. Engelhardt, G.; Michell, D. High-Resolution Solid-State RMN of Silicates and Zeolites; Wiley \& Sons: New Delhi, India, 1987.

73. Richardson, I.G.; Brough, A.R.; Groves, G.W.; Dobson, C.M. The characterization of hardened alkali-activated blast furnace slag pastes and the nature of the calcium silicate hydrate $(\mathrm{C}-\mathrm{S}-\mathrm{H})$ phase. Cem. Concr. Res. 1994, 24, 813-829. [CrossRef]

74. Pardal, X.; Pochard, I.; Nonat, A. Experimental study of Si-Al substitution in calcium-silicate-hydrate (C-S-H) prepared under equilibrium conditions. Cem. Concr. Res. 2009, 39, 637-664. [CrossRef]

75. Sun, G.K.; Young, J.F.; Kirkpatrick, R.J. The role of Al in C-S-H: NMR, XRD, and compositional results for precipitated samples. Cem. Concr. Res. 2006, 36, 18-29. [CrossRef]

76. Bentz, D.P.; Hansen, A.S.; Guynn, J.M. Optimization of cement and fly ash particle sizes to produce sustainable concretes. Cem. Concr. Compos. 2011, 33, 824-831. [CrossRef]

77. Garcia-Lodeiro, I.; Fernández-Jiménez, A.; Palomo, A. Chemistry, Mix Designed and Manufacture of Alkali Activated Cement Based Concretes-Mixtures. Handbook of Alkali-Activated Cements, Mortars and Concretes. Available online: http://dx.doi.org/10.1533/978-1-78242-288-4.1.49 (accessed on October 2015).

78. Palomo, A.; Krivenko, P.; Garcia-Lodeiro, I.; Kavalerova, E.; Maltseva, O.; Fernandez-Jimenez, A. A review on alkaline activation: New analytical perspectives. Mater. Constr. 2014, 64. [CrossRef]

79. Sant, G.; Kumar, A.; Patapy, C.; Le Saout, G.; Scrivener, K. The influence of sodium and potassium hydroxide on volume changes in cementitious materials. Cem. Concr. Res. 2012, 42, 1447-1455. [CrossRef]

80. McLellan, B.C.; Williams, R.P.; Lay, J.; van Riessen, A.; Corder, G.D. Costs and carbon emissions for geopolymer pastes in comparison to ordinary Portland cement. J. Clean. Prod. 2011, 19, 1080-1090. [CrossRef]

81. Duxson, P.; Provis, J.L.; Lukey, G.C.; van Deventer, J.S.J. The role of inorganic polymer technology in the development of "green concrete". Cem. Concr. Res. 2007, 37, 1590-1597. [CrossRef]

82. Justnes, J.H.; Østnor, T.A. Designing Alternative Binders Utilizing Synergic Reactions. In Proceedings of the NTCC2014: International Conference on Non-Traditional Cement and Concrete, Brno, Czech Republic, 16-19 June 2014; pp. 1-4.

83. Li, G.; Le Bescop, P.; Moranville, M. The U phase formation in cement-based systems containing high amounts of $\mathrm{Na}_{2} \mathrm{SO}_{4}$. Cem. Concr. Res. 1996, 26, 27-33. [CrossRef]

84. Sanchez-Herrero, M.J.; Fernández-Jiménez, A.; Palomo, A. Alkaline hydration of tricalcium aluminate. J. Am. Ceram. Soc. 2012, 95, 3317-3324. [CrossRef]

(C) 2016 by the authors; licensee MDPI, Basel, Switzerland. This article is an open access article distributed under the terms and conditions of the Creative Commons Attribution (CC-BY) license (http://creativecommons.org/licenses/by/4.0/). 